International Journal of Agriculture, Environment and Bioresearch

Vol. 4, No. 03; 2019

ISSN: $2456-8643$

\title{
IMPORTANCE, HEALTH BENEFITS AND BIOACTIVITIES OF SRI LANKAN TRADITIONAL RICE (Oryza sativa L.) VARIETIES: A REVIEW
}

Pitipana Achchige Nadini Thushara, Pahan. I. Godakumbura*, M. A. B. Prashantha

Department of Chemistry, University of Sri Jayewardenepura, Nugegoda 10250, Sri Lanka

http://doi.org/10.35410/IJAEB.2019.119128

\begin{abstract}
Rice is the major staple food of almost half of the world's population. It has significant nutrition and health implications. Being a major energy contributor to the body of rice consuming population, there is a huge increasing concern on rice worldwide. Sri Lankan traditional rice varieties have scientifically proven high nutritional values, low glycemic indices with antidiabetic effect, anticancer potency against human lung cancer cells, antiglycation and antiamylase effects. This review gathers studies mainly on health benefits and bioactivities of Sri Lankan traditional rice varieties and provides a critical overview of the current states of the consumption and benefits of rice
\end{abstract}

Keywords: Sri Lankan traditional rice, nutritional value, antioxidants, cytotoxicity, diabetic.

\section{INTRODUCTION}

Rice is the highest priority cereal crop and the main staple food in Asia among the world. It is the second largest quantity staple international traded cereal after wheat. More than 5000 varieties of rice available in all over the world (Bhattacharjee et al., 2002). Approximately 95\% of rice production is done in Asia. According to FAOSTAT (2016), in 2016 China was the major rice producer with 211 Mio tonnes while Sri Lanka with 4.1 Mio tonnes. Even though white rice is the most popular rice type among consumers, there are many types of rice cultivars known as black rice, red rice and brown rice according to their color pigments. Their names were given referring to the kernel color such as black, red, brown or purple which is formed by anthocyanin depositions in pericarp, seed coat and aleurone layers (Chaudhary, 2003). Chaudhary (2003)reported that China (62\%) is the richest country in black rice resources of followed by Sri Lanka (8.6\%), Indonesia (7.2\%), India (5.1\%) and rest in Philippines, Bangladesh, Malaysia, Thailand and Myanmar. Most of Indian and Pakistan indigenous rice varieties show various health benefits and bioactivities. Morphological, physicochemical and cooking properties of Indian rice cultivars of four non-basmati(namely Jaya, P-44, HKR-120, Sharbati) and two basmati(namely HBC-19 and Bas-370)have been studied.(Yadav et al., 2007)23 varieties of Indian milled ricehave been evaluated for physicochemical, cooking and textural properties. (Singh et al., 2005)The antioxidant activity of five Pakistan indigenous rice bran varieties have 
been evaluated and antioxidant power was correlated with growth period and irrigation water demand by a particular variety (rice bran-Super kernel) which shown the highest antioxidant activity among all. (Iqbal et al., 2005) Studies have shown that the Indian brown rice is nutritionally superior to fully polished rice varieties.(Shobana et al., 2011)Because of the high nutritional and medicinal values, Sri Lankan traditional rice varieties are also becoming popularized. Traditional rice had been used to cure various disease conditions in traditional medical practices in Sri Lanka (Buddhadasa, 1960, Weralupitiya, 1994, Seelarathana, 1927)

\section{REVIEW}

\subsection{Composition of rice grain}

Rice grain with its bran contains significant quantities of all the major nutrients, including predominant macronutrient, carbohydrate $(32.1 \mathrm{~g} / 100 \mathrm{~g}$ grain), protein $(2.6 \mathrm{~g} / 100 \mathrm{~g}$ grain), fat $(1.1 \mathrm{~g} / 100 \mathrm{~g}$ grain), and fiber $(0.8 \mathrm{~g} / 100 \mathrm{~g}$ grain) (Schenker, 2012). The energy content of white rice is slightly less than the brown rice due to the removal of bran which is consisting lipid(Champagne et al., 2004). Numerous studies have attempted to explain that white rice which is produced from polishing of brown rice has lower fat, protein, fiber, ash, vitamins and polyphenols(Shobana et al., 2011, Champagne et al., 2004). Health benefits of rice can be emphasized in terms of their activities of phytochemicals such as phenolic compounds. Several studies have been carried out on pigmented rice varieties and have shown that aleurone layer consists of higher amounts of phenolic compounds and possess strong antioxidant activities(Nam et al., 2006, Finocchiaro et al., 2010). The major flavonoids in rice extracts were identified as anthocyanins and procyanidins for black and red rice, respectively (Ichikawa et al., 2001)while the other phytochemicals are $\gamma$-oryzanols, vitamin $\mathrm{E}$ homologues, phenolic acids, etc. (Zawistowski et al., 2009, Chung and Shin, 2007, Yawadio et al., 2007). Phytochemicals present in rice grain are powerful antioxidants and responsible to reduce atherosclerotic plague formation(Ling et al., 2001), inhibit aldose reductase activity(Yawadio et al., 2007), decrease hyperlipidemia (Guo et al., 2007)and suppress cancer cell proliferation (Nam et al., 2005). Furthermore, investigations have shown higher cytotoxic potential of black rice against HL-60 cells. (Vichit and Saewan, 2015)

\subsection{Importance of Sri Lankan traditional rice varieties}

The rice varieties passed down from former generations are known as 'traditional', 'indigenous' or 'inheritance' rice varieties of Sri Lanka (Rambukwella and Priyankara, 2016). Sri Lanka is a rich treasurable land of traditional rice cultivation and historically, rice has a major part of diet and culture. According to the reports, in ancient times, about 2000 conserved different traditional rice varieties known to have existed in Sri Lanka (Priyangani et al., 2008). After 1950,demand for the many of the traditional ricevarieties were reduced due to the introducing of new improved rice varieties to the Sri Lankan rice market. Despite the fact that these improved varietieswere short in terms of age, high yielding, and fertilizer dependentis causing negative impact to the environment(Steve Wiggins et al., 2010). Almost all the STRV were organically farmed, which relies on techniques such as crop rotation, green manure, compost, biological pest control, spiritual practices and depends on ancient irrigation systems and for a sustained water supply. In addition, the specialties of traditional ricecan be highlighted asresistant to extreme climatic conditions, soil conditions, diseases and pests (Ranawake et al., 2013). A recent literature on 
submerge tolerance shows that some traditional ricevarieties have more than $70 \%$ survival rates at 14 day stress period (Murunga Wee :84.3\%, Lumbini :88.5\%, Jamis wee :88.1\% and Wanni Heenati :70.9\%). In this study, out of 20 rice cultivars Muthumanikam (100\%) Jamis Wee (73.0\%), Rajes (93.7\%), Madael Kalutara (71.4\%), Lumbini $(80.7 \%)$, and Murunga Wee (96.1\%) recorded more than $70 \%$ survival rates at 9 day stress period (Hewage et al., 2013). In another major study, Ranawake (2010)found thatRandhunipagal, Valihandira, Matholuwa, Kahata wee, Mas Samba and Surumaniyan are tolerant to complete submergence for 7 days (Ranawake et al., 2010).Over the past decade, the world has seen the benefits of consuming organic foods and the disadvantages of using chemical fertilizerand pesticides. Thereafter in recent years, interest ontraditional rice varieties has beenincreased as they are not depending on chemical fertilizers. Surveys such as Rambukwella and Priyankara (2016)showed that, there is a good trend in consuming traditional rice varieties mostly the consumers suffering from noncommunicable diseases. According to the findings, about $71 \%$ of the consumers had started to consume traditional rice varieties in less than a year. Among these consumers, $79 \%$ reported that they used that rice varieties as a solution for diabetes and $21 \%$ reported that they used traditional rice for other diseases. The most popular varieties were Suwandel (49\%), Kuruluthuda (29\%), Pachchaperumal (27\%) and Kahawanu (18\%) among the sample farmers and consumers. On the other hand, about $72 \%$ of the total sample had not used agro chemical and weedicide (Rambukwella and Priyankara, 2016). Re-establishment and development of traditional rice varieties selected by mass selection method have been reported in different countries (Gravois and McNew, 1993, Almekinders and Elings, 2001, Gyawali et al., 2007).

\subsection{Health benefits and bioactivities of Sri Lankan traditional rice varieties}

A considerable amount of literature has been published on health benefits of Sri Lankan traditional rice varieties. This section focuses on the nutritional values, health benefits and bioactivities of Sri Lankan traditional rice varieties. Kariyawasam et al. (2016b) analyzed the data for six traditional rice varieties; Kalu heenati, Pokkali, Gurusinghe wee, Kahawanu, Sudu murunga, Unakola sambaand concluded thatSri Lankan traditional rice varieties possess high nutritional values than those values reported for the improved rice. The results revealed that the highest values for protein content, crude fiber and crude fat content reported for Kalu Heenati $(9.7 \pm 0.3 \%)$, Sudu Murunga $(1.14 \pm 0.04 \%)$ Unakola Samba(2.3 $\pm 0.0 \%)$ respectively(Kariyawasam et al., 2016b). Likewise a number of researchers have reported on proximate compositions of traditional and improved rice varieties in Sri Lanka as well as Thailand and China. Chemical properties and bioactivities of evaluated rice varieties are differ from country to country(Sompong et al., 2011, Perera et al., 2014).

More recent attention has focused on mineral contents of parboiled and un-parboiled traditional rice varieties (Kariyawasam et al., 2016a). The results proved the two aspects related to paddy processing: effect of par-boiling on mineral content depends on the rice variety regardless of color of the pericarp andappreciably high iron and zinc contents present in traditional rice compared to that of improved varieties in Sri Lanka. Thus the authors suggest that the both parboiled and un-parboiled Pokkali (iron content: $29.5 \mathrm{mg} / 100 \mathrm{~g}$ ) can be considered as a suitable dietary supplement for iron deficiency for pregnant mothers. (Kariyawasam et al., 2016a). 
Vol. 4, No. 03; 2019

ISSN: $2456-8643$

Some authors have mainly been interested in questions concerning contaminations of toxic heavy metals in rice (Kariyawasam et al., 2016b) because recently there are some findings show that Sri Lanka rice varieties are contaminated with some toxic heavy metals such as As and Cd(Bandara et al., 2008, Jayasumana et al., 2015). By addressing to above claims, Kariyawasam et al. (2016a) and (Kariyawasam et al., 2016b) reported that traditional rice varieties (study sample of six varieties) do not cause any toxic effects due to $\mathrm{As}, \mathrm{Cd}, \mathrm{Cu}$ and $\mathrm{Pb}$.

Much of the current literature pays particular attention to physicochemical properties of rice. Frequent consumption of high GI and high glycemic load (GL) meals is connected with development of diabetes. Recent meta-analysis study demonstrates that high consumption of rice causes the diabetes and this study showed that consumption of white rice relates to the type 2 diabetes mainly among Asian population (Hu et al., 2012).Among nine red and three black rice varieties from Thailand, China and Sri Lanka, the highest amylose contents(40\%) represented the three Sri Lankan rice varieties and one Thailand rice variety (SRI1, SRI2, SRI3 and LP) (Sompong et al., 2011). Nevertheless low amylose rice (0-2\%, waxy) tend to rapid starch hydrolysis than high amylose cultivars (>25\%) (Hu et al., 2004, Frei et al., 2003), which contributes to its higher impact on glycaemia (Goddard et al., 1984). The literature suggests that the importance of having high amylose value of rice is corresponds to the lower glycemic index (GI)values and it resulted in attenuated insulin responses(Goddard et al., 1984, Juliano and Goddard, 1986).Studies conducted on Sri Lankan traditional and improved rice varieties showed that mediam to high amylose content (57-73). In this study, Wedaheenati rice exhibited the lowest GI (57) while the highest in improved Bg 406 variety (73) (Pathiraje et al., 2010). Several studies thus far have linked GI with not only rice, but the rice products also. Widanagamage et al. (2009) found that rice flour roti which is made from AT353 rice variety has high GI (103) value. Parboiled rice with Amaranthus leaf curry was classified as low GI (47) meal (Pirasath et al., 2010) whereas plain form of white rice have a relatively higher GI (50-92) (Ranawana et al., 2009). When consuming legumes and rice together, it causes the lowering of GI (Hettiaratchi et al., 2009). However, in contrast to above findings Hettiarachchi et al. (2014) emphasized that parboiled varieties of red rice as well as Bg 350 improved variety have the low GI values (56-73) compared to some of the un-parboiled red rice and white rice. As reported there, authors highlighted that red parboiled varieties of rice and $\mathrm{Bg} 350$ can be recommended for patients with diabetes (Hettiarachchi et al., 2014).

Research conducted in last two decades has shown that rice bran contains a unique complex of naturally occurring antioxidant compounds (MOLDENHAUER et al., 1998). One such study presented thus far provide evidence that brans of Sri Lankan traditional red rice namely Masuran, Dik Wee, Goda Heeneti and Sudu Heeneti possess marked antioxidant properties and consumption may play an vital role in prevention of oxidative stress associated chronic diseases(Abeysekera et al., 2011).

Remarkable antioxidant capacity of eight traditional Sri Lankan red grained rice varieties has been evaluated (Gunaratne et al., 2013). Results have shown that all the tested traditional rice varieties have over sevenfold higher both total antioxidant capacity and phenolic content than three light brown-grained new-improved rice varieties.Major compounds of proanthocyanidins, phenolic acids and oryzanols (ferulic acid derivatives) have been identified as key contributing factors for the apparently high amount of antioxidant capacity. Further, Proanthocyanidins were detected only in the traditional red varieties, hence authors conclude that traditional rice is 
effective in fighting kidney and liver diseases, heart diseases, diabetes, cancer etc (Gunaratne et al., 2013).According to the study conducted using rice varieties from Thailand, china and Sri Lanka, Cyanidin 3-glucoside and peonoidin 3-glucoside were confirmed as the dominant anthocyanins which corresponds to the high antioxidant properties(Sompong et al., 2011). Among the bioactivity studies, Premakumara et al. (2013)was apparently the first to prove the in vitro glycation reversing and presence of anti-glycation activity of Sri Lankan rice bran of 23 traditional and 12 improved (both red and white) rice varieties. Moreover, in this study, significantly high antiamylase and anti-glycation activities were observed for bran extracts of traditional red rice varieties, Masuran, Sudu Heeneti, Dik Wee and Goda Heeneti, compared to improved red rice varieties. findings of this study indicate the potential of using brans of Sri Lankan traditional rice varieties as potential pharmaceuticals for diabetes and related complications(Premakumara et al., 2013).

Godakumbura et al. (2016) points out the antibacterial activity of selected Sri Lankan traditional rice varieties (parboiled and un-parboiled). Rathdal, Kalu Heenati, Pokkali and Kahawanu exhibited a potent antibacterial activity against Staphylococcus aureus with minimum bactericidal concentrations (MBC) of $200 \mu \mathrm{g} / \mathrm{mL}$. Kalu Heenati, Pokkali and Rathdal showed an efficacious inhibitory effect against Methicillin resistant Staphylococcus aureus (MRSA) (MBC; $200 \mu \mathrm{g} / \mathrm{mL}$ ). However, after subjected to parboiling, loss of antibacterial activity was detected in rice. Finally authors conclude, Sri Lankan traditional rice varieties with red pericarp possess high antibacterial activity against Gram positive bacteria (Godakumbura et al., 2016).

One of the most important investigation illustrated the potential anti- cancer activity of rice bran of four Sri Lankan traditional varieties (Goda Heeneti, Sudu Heeneti, Dik Wee and Sudu Heeneti) (Abeysekera et al., 2015). The results revealed that mentioned rice varieties have growth inhibition and cytotoxicity against human lung cancer (NCI-H460) and cervical cancer (HeLa) cell lines and GST inhibitory activity in vitro. From the point of view of growth inhibition and cytotoxicity, it is becoming apparent that some of the Sri Lankan traditional rice varieties possess promising ability for management of cancer(Abeysekera et al., 2015).

A recent study showed that risk of developing diabetes can be significantly reduced by consuming brown rice instead of white rice(Sun et al., 2010). Red and brown rice possess numerous nutritional advantages over common rice, for instance a higher content of protein, vitamins and minerals, although there are genetic variations and geographic variations(NAKAGAHRA et al., 1975).And also anthocyanin pigments in rice have been reported to be highly effective in reducing cholesterol levels in the human body(Lee et al., 2008). One top of that inhibitory effects of pigmented rice bran on allergic reactions were also identified (Choi et al., 2007).

\section{CONCLUSION}

The studies reviewed in this articleappeared to focus on importance of Sri Lankan traditional rice varieties. Nevertheless, most of the studies revealed that Sri Lankan traditional rice varieties exhibit great health benefits and bio activities in contrast to the improved varieties. Thus, intervention studies suggest that traditional rice may be the best substituent to improved rice to maintain low GI and cholesterol levels, reduce the risk of heart diseases and cancer cell 
proliferationetc. But nutritional values of most of the unpopular traditional rice varieties are still scientifically not proven. A few rice varieties of traditional cultivars have scientifically proven antidiabetic, cytotoxic, antiglycation, antiamylase effects. Therefore further studies on these valuable traditional rice varieties and uncovering the health benefits and bio activities of these rice varieties have become important.

\section{ACKNOWLEDGEMENT}

The authors gratefully acknowledge University of Sri Jayewardenepura (research grant: ASP/01/RE/SCI/2017/54) for the financial support.

\section{REFERENCES}

ABEYSEKERA, W., PREMAKUMARA, G., DAR, A., CHOUDHARY, M. I., RATNASOORIYA, W., KASHIF, M., MUDASSAR, C., ALI, S. \& CHANDRASEKHARAN, N. 2015. Growth Inhibition and Cytotoxicity in Human Lung and Cervical Cancer Cell Lines and Glutathione S-Transferase Inhibitory Activity of Selected S ri L ankan Traditional Red Rice (O ryza Sativa L.) Brans. Journal of food biochemistry, 39, 585-593.

2. ABEYSEKERA, W., PREMAKUMARA, G., RATNASOORIYA, W. \& CHANDRASEKHARAN, N. 2011. Antioxidant properties of some Sri Lankan traditional red rice (Oryza sativa L.).

3. ALMEKINDERS, C. \& ELINGS, A. 2001. Collaboration of farmers and breeders: Participatory crop improvement in perspective. Euphytica, 122, 425-438.

4. BANDARA, J., SENEVIRATHNA, D., DASANAYAKE, D., HERATH, V., BANDARA, J., ABEYSEKARA, T. \& RAJAPAKSHA, K. 2008. Chronic renal failure among farm families in cascade irrigation systems in Sri Lanka associated with elevated dietary cadmium levels in rice and freshwater fish (Tilapia). Environmental Geochemistry and Health, 30, 465-478.

5. BHATTACHARJEE, P., SINGHAL, R. S. \& KULKARNI, P. R. 2002. Basmati rice: a review. International journal of food science \& technology, 37, 1-12.

6. BUDDHADASA, R. 1960. Charaka Sanhithawa. Department of official languages, Sri Lanka.

7. CHAMPAGNE, E. T., WOOD, D. F., JULIANO, B. O. \& BECHTEL, D. B. 2004. The rice grain and its gross composition. Rice chemistry and technology, 3, 77-107.

8. CHAUDHARY, R. 2003. Speciality rices of the world: effect of WTO and IPR on its production trend and marketing.

9. CHOI, S. P., KANG, M. Y., KOH, H. J., NAM, S. H. \& FRIEDMAN, M. 2007. Antiallergic activities of pigmented rice bran extracts in cell assays. Journal of food science, 72, S719-S726. 
10. CHUNG, H. S. \& SHIN, J. C. 2007. Characterization of antioxidant alkaloids and phenolic acids from anthocyanin-pigmented rice (Oryza sativa cv. Heugjinjubyeo). Food chemistry, 104, 1670-1677.

\section{FAOSTAT 2016.}

12. FINOCCHIARO, F., FERRARI, B. \& GIANINETTI, A. 2010. A study of biodiversity of flavonoid content in the rice caryopsis evidencing simultaneous accumulation of anthocyanins and proanthocyanidins in a black-grained genotype. Journal of Cereal Science, 51, 28-34.

13. FREI, M., SIDDHURAJU, P. \& BECKER, K. 2003. Studies on the in vitro starch digestibility and the glycemic index of six different indigenous rice cultivars from the Philippines. Food Chemistry, 83, 395-402.

14. GODAKUMBURA, P. I., KARIYAWASAM, T. I., ARACHCHI, P. M., FERNANDO, N. \& PREMAKUMARA, S. 2016. In-vitro Antibacterial Activity of Sri Lankan Traditional Rice (Oryza sativa L.) Extracts against Bacteria Causing Skin and Soft Tissue Infections.

15. GODDARD, M. S., YOUNG, G. \& MARCUS, R. 1984. The effect of amylose content on insulin and glucose responses to ingested rice. The American journal of clinical nutrition, 39, 388-392.

16. GRAVOIS, K. A. \& MCNEW, R. W. 1993. Genetic relationships among and selection for rice yield and yield components. Crop Science, 33, 249-252.

17. GUNARATNE, A., WU, K., LI, D., BENTOTA, A., CORKE, H. \& CAI, Y.-Z. 2013. Antioxidant activity and nutritional quality of traditional red-grained rice varieties containing proanthocyanidins. Food chemistry, 138, 1153-1161.

18. GUO, H., LING, W., WANG, Q., LIU, C., HU, Y., XIA, M., FENG, X. \& XIA, X. 2007. Effect of anthocyanin-rich extract from black rice (Oryza sativa L. indica) on hyperlipidemia and insulin resistance in fructose-fed rats. Plant Foods for Human Nutrition, 62, 1-6.

19. GYAWALI, S., SUNWAR, S., SUBEDI, M., TRIPATHI, M., JOSHI, K. \& WITCOMBE, J. 2007. Collaborative breeding with farmers can be effective. Field Crops Research, 101, 88-95.

20. HETTIARACHCHI, P., JIFFRY, M., JANSZ, E., WICKRAMASINGHE, A. \& FERNANDO, D. 2014. Glycaemic indices of different varieties of rice grown in Sri Lanka. Ceylon Medical Journal, 46.

21. HETTIARATCHI, U., EKANAYAKE, S. \& WELIHINDA, J. 2009. Do Sri Lankan meals help decrease blood glucose response? Ceylon Medical Journal, 54.

22. HEWAGE, M., RANAWAKE, A., DAHANAYAKE, N. \& SUBASINGHE, S. Understanding submergence tolerance of some traditional rice cultivars at vegetative stage. ISAE 2013. Proceedings of the International Symposium on Agriculture and Environment 2013, 
28 November 2013, University of Ruhuna, Sri Lanka, 2013. Faculty of Agriculture, University of Ruhuna, 484-488.

23. HU, E. A., PAN, A., MALIK, V. \& SUN, Q. 2012. White rice consumption and risk of type 2 diabetes: meta-analysis and systematic review. Bmj, 344, e1454.

24. HU, P., ZHAO, H., DUAN, Z., LINLIN, Z. \& WU, D. 2004. Starch digestibility and the estimated glycemic score of different types of rice differing in amylose contents. Journal of Cereal Science, 40, 231-237.

25. ICHIKAWA, H., ICHIYANAGI, T., XU, B., YOSHII, Y., NAKAJIMA, M. \& KONISHI, T. 2001. Antioxidant activity of anthocyanin extract from purple black rice. Journal of medicinal food, 4, 211-218.

26. IQBAL, S., BHANGER, M. \& ANWAR, F. 2005. Antioxidant properties and components of some commercially available varieties of rice bran in Pakistan. Food chemistry, 93, 265-272.

27. JAYASUMANA, C., FONSEKA, S., FERNANDO, A., JAYALATH, K., AMARASINGHE, M., SIRIBADDANA, S., GUNATILAKE, S. \& PARANAGAMA, P. 2015. Phosphate fertilizer is a main source of arsenic in areas affected with chronic kidney disease of unknown etiology in Sri Lanka. SpringerPlus, 4, 90.

28. JULIANO, B. O. \& GODDARD, M. S. 1986. Cause of varietal difference in insulin and glucose responses to ingested rice. Plant Foods for Human Nutrition, 36, 35-41.

29. KARIYAWASAM, T., GODAKUMBURA, P., PRASHANTHA, M. \& PREMAKUMARA, G. 2016a. Effect of parboiling on minerals and heavy metals of selected Sri Lankan traditional rice varieties grown under organic farming. Tropical Agricultural Research and Extension, 19, 168-172.

30. KARIYAWASAM, T., GODAKUMBURA, P., PRASHANTHA, M. \& PREMAKUMARA, G. 2016b. Proximate composition, calorie content and heavy metals (As, $\mathrm{Cd}, \mathrm{Pb}$ ) of selected Sri Lankan traditional rice (Oryza sativa L.) varieties. Procedia food science, 6, 253-256.

31. LEE, J. C., KIM, J. D., HSIEH, F. H. \& EUN, J. B. 2008. Production of black rice cake using ground black rice and medium-grain brown rice. International journal of food science \& technology, 43, 1078-1082.

32. LING, W. H., CHENG, Q. X., MA, J. \& WANG, T. 2001. Red and black rice decrease atherosclerotic plaque formation and increase antioxidant status in rabbits. The Journal of nutrition, 131, 1421-1426.

33. MOLDENHAUER, K., CHAMPAGNE, E. \& GURAYA, H. 1998. Functional Products From Rice. Functional Foods: Biochemical and Processing Aspects, 1, 71. 
34. NAKAGAHRA, M., AKIHAMA, T. \& HAYASHI, K.-I. 1975. Genetic variation and geographic cline of esterase isozymes in native rice varieties. The Japanese Journal of Genetics, 50, 373-382.

35. NAM, S. H., CHOI, S. P., KANG, M. Y., KOH, H. J., KOZUKUE, N. \& FRIEDMAN, M. 2006. Antioxidative activities of bran extracts from twenty one pigmented rice cultivars. Food Chemistry, 94, 613-620.

36. NAM, S. H., CHOI, S. P., KANG, M. Y., KOZUKUE, N. \& FRIEDMAN, M. 2005. Antioxidative, antimutagenic, and anticarcinogenic activities of rice bran extracts in chemical and cell assays. Journal of Agricultural and Food Chemistry, 53, 816-822.

37. PATHIRAJE, P., MADHUJITH, W., CHANDRASEKARA, A. \& NISSANKA, S. 2010. The effect of rice variety and parboiling on in vivo glycemic response.

38. PERERA, M., SIVAKANESAN, R., ABEYSEKARA, D. \& SARANANDA, K. 2014. Sensory evaluation, proximate analysis and available carbohydrate content of soy flour incorporated cereal based traditional Sri Lankan breakfast foods. International Journal, 1, 23112476.

39. PIRASATH, S., THAYAANANTHAN, K., BALAKUMAR, S. \& ARASARATNAM, V. 2010. Effect of dietary curries on the glycaemic index. Ceylon Medical Journal, 55.

40. PREMAKUMARA, G., ABEYSEKERA, W., RATNASOORIYA, W., CHANDRASEKHARAN, N. \& BENTOTA, A. 2013. Antioxidant, anti-amylase and antiglycation potential of brans of some Sri Lankan traditional and improved rice (Oryza sativa L.) varieties. Journal of cereal science, 58, 451-456.

41. PRIYANGANI, E., KOTTEARACHCHI, N., ATTANAYAKA, D. \& PATHINAYAKE, B. 2008. Characterization of Suwandal and Heenati rice varieties for the fragrance gene using Polymerase Chain Reaction based molecular markers. Faculty of Agriculture and plantation management, Wayamba University of Sri Lanka.

42. RAMBUKWELlA, R. \& PRIYANKARA, E. 2016. Production and Marketing of Traditional Rice Varieties in Selected Districts in Sri Lanka: Present Status and Future Prospects.

43. RANAWAKE, A., AMARASINGHA, U. \& DAHANAYAKE, N. 2013. Agronomic characters of some traditional rice (Oryza sativa L.) cultivars in Sri Lanka. Journal of the University of Ruhuna, 1.

44. RANAWAKE, A., DAHANAYAKE, N. \& SENADHIPATHI, D. 2010. Evaluation of level of submergence tolerance in traditional rice cultivars at post-germination stage. proceedings of the abstract of 8th Academic session, University of Ruhuna, 203.

45. RANAWANA, D., HENRY, C., LIGHTOWLER, H. \& WANG, D. 2009. Glycaemic index of some commercially available rice and rice products in Great Britain. International journal of food sciences and nutrition, 60, 99-110. 
46. SCHENKER, S. 2012. An overview of the role of rice in the UK diet. Nutrition Bulletin, 37, 309-323.

47. SEELARATHANA, H. 1927. Sarartha sangraha. D. C. Wickramasinghe Appuhamy.

48. SHOBANA, S., MALlEShI, N., SUDHA, V., SPIEGELMAN, D., HONG, B., HU, F., WILLETT, W., KRISHNASWAMY, K. \& MOHAN, V. 2011. Nutritional and sensory profile of two Indian rice varieties with different degrees of polishing. International journal of food sciences and nutrition, 62, 800-810.

49. SINGH, N., KAUR, L., SODHI, N. S. \& SEKHON, K. S. 2005. Physicochemical, cooking and textural properties of milled rice from different Indian rice cultivars. Food Chemistry, 89, 253-259.

50. SOMPONG, R., SIEBENHANDL-EHN, S., LINSBERGER-MARTIN, G. \& BERGHOFER, E. 2011. Physicochemical and antioxidative properties of red and black rice varieties from Thailand, China and Sri Lanka. Food Chemistry, 124, 132-140.

51. STEVE WIGGINS, O., BROOKS, J. \& SECRETARIAT, O. 2010. The Use of Input Subsidies in Developing Countries.

52. SUN, Q., SPIEGELMAN, D., VAN DAM, R. M., HOLMES, M. D., MALIK, V. S., WILLETT, W. C. \& HU, F. B. 2010. White rice, brown rice, and risk of type 2 diabetes in US men and women. Archives of internal medicine, 170, 961-969.

53. VICHIT, W. \& SAEWAN, N. 2015. Antioxidant activities and cytotoxicity of Thai pigmented rice. Int J Pharm Pharm Sci, 7, 329-334.

54. WERALUPITIYA, N. W. 1994. Thalapathe piliyam. Department of Ayurveda, Colombo.

55. WIDANAGAMAGE, R. D., EKANAYAKE, S. \& WELIHINDA, J. 2009. Carbohydraterich foods: glycaemic indices and the effect of constituent macronutrients. International journal of food sciences and nutrition, 60, 215-223.

56. YADAV, R., KHATKAR, B. \& YADAV, B. 2007. Morphological, physicochemical and cooking properties of some Indian rice (Oryza sativa L.) cultivars. Journal of Agricultural Technology, 3, 203-210.

57. YAWADIO, R., TANIMORI, S. \& MORITA, N. 2007. Identification of phenolic compounds isolated from pigmented rices and their aldose reductase inhibitory activities. Food Chemistry, 101, 1616-1625.

58. ZAWISTOWSKI, J., KOPEC, A. \& KITTS, D. D. 2009. Effects of a black rice extract (Oryza sativa L. indica) on cholesterol levels and plasma lipid parameters in Wistar Kyoto rats. Journal of Functional Foods, 1, 50-56. 